\title{
Scientific Collaboration on Past Speciation Conditions in Lake Ohrid-SCOPSCO Workshop Report
}

\author{
by Bernd Wagner, Thomas Wilke, Sebastian Krastel-Gudegast, Andon Grazhdani, \\ Klaus Reicherter, Sasho Trajanovski, and Giovanni Zanchetta
}

doi:10.2204/iodp.sd.7.08.2009

Transboundary Lake Ohrid between Albania and Macedonia (SE Europe, Fig. 1) is considered to be the oldest continuously existing lake in Europe with a likely age of three to five million years. The lake has a surface area of 360 $\mathrm{km}^{2}$ and is $289 \mathrm{~m}$ deep. An extraordinarily high degree of endemism, including more than 210 described endemic species (Fig. 2), makes the lake a unique aquatic ecosystem of worldwide importance. Due to its old age, Lake Ohrid is one of the very few lakes in the world representing a hot spot of evolution and a potential evolutionary reservoir enabling the survival of relict species (Albrecht and Wilke, 2008). Its importance was emphasized when the lake was declared a UNESCO World Heritage Site in 1979.

The continuous existence since the Tertiary makes Lake Ohrid an excellent archive of environmental changes in the northern Mediterranean region. Because of its geographic position and its presumed age, Lake Ohrid represents an important link between climatic and environmental records from the Mediterranean Sea and the adjacent continents. In the eastern Mediterranean Sea, most records focus on the Late Pleistocene and Holocene history (Geraga et al., 2005), and only few cover several glacial-interglacial cycles (Schmiedl et al., 1998). Similarly, most terrestrial records from this region are restricted to the Late Pleistocene and Holocene (Denèfle et al., 2000; Sadori and Narcisi, 2001). Longer continuous records covering more than the last glacial-interglacial cycle are relatively sparse (Wijmstra, 1969; Tzedakis et al., 1997). Extant sedimentary records from Lake Ohrid were recovered during field campaigns in 1973 (Roelofs and Kilham, 1983) and more recently between 2001 and 2007 (Belmecheri et al., 2007; Matzinger et al., 2007; Wagner et al., 2008a, 2008b). These records cover (with some hiatuses) the past glacial-interglacial cycle and reveal that Lake Ohrid is a valuable archive of volcanic ash dispersal and climate change in the northern Mediterranean region. However, with respect to the extraordinarily high en- demism in the lake, these records are too short to provide information about the age and origin of the lake and to unravel the mechanisms controlling the evolutionary development. Molecular clock analyses of mitochondrial DNA genes from several endemic species flocks (i.e., groups of closely related species) indicate that Lake Ohrid is probably two to three million years old (Albrecht and Wilke, 2008). Moreover, concurrent genetic breaks in several invertebrate groups indicate that major geological and/or environmental events must have shaped the evolutionary history of endemic faunal elements in Lake Ohrid (Albrecht and Wilke, 2008).

Different site surveys between 2004 and 2008 (Wagner et al., 2008b) focused on a detailed seismic investigation of the sedimentological inventory of the lake and on the recovery of sediment sequences spanning the last glacial-interglacial cycle. The results of these site surveys emphasized the potential of Lake Ohrid for deep drilling. Such a drilling will allow us to:

- understand the impact of major geological/environmental events on general evolutionary patterns and on generating an extraordinary degree of endemic biodiversity as a matter of global significance,

- obtain a continuous record containing information on tectonic and volcanic activities and climate changes in the northern Mediterranean region, and

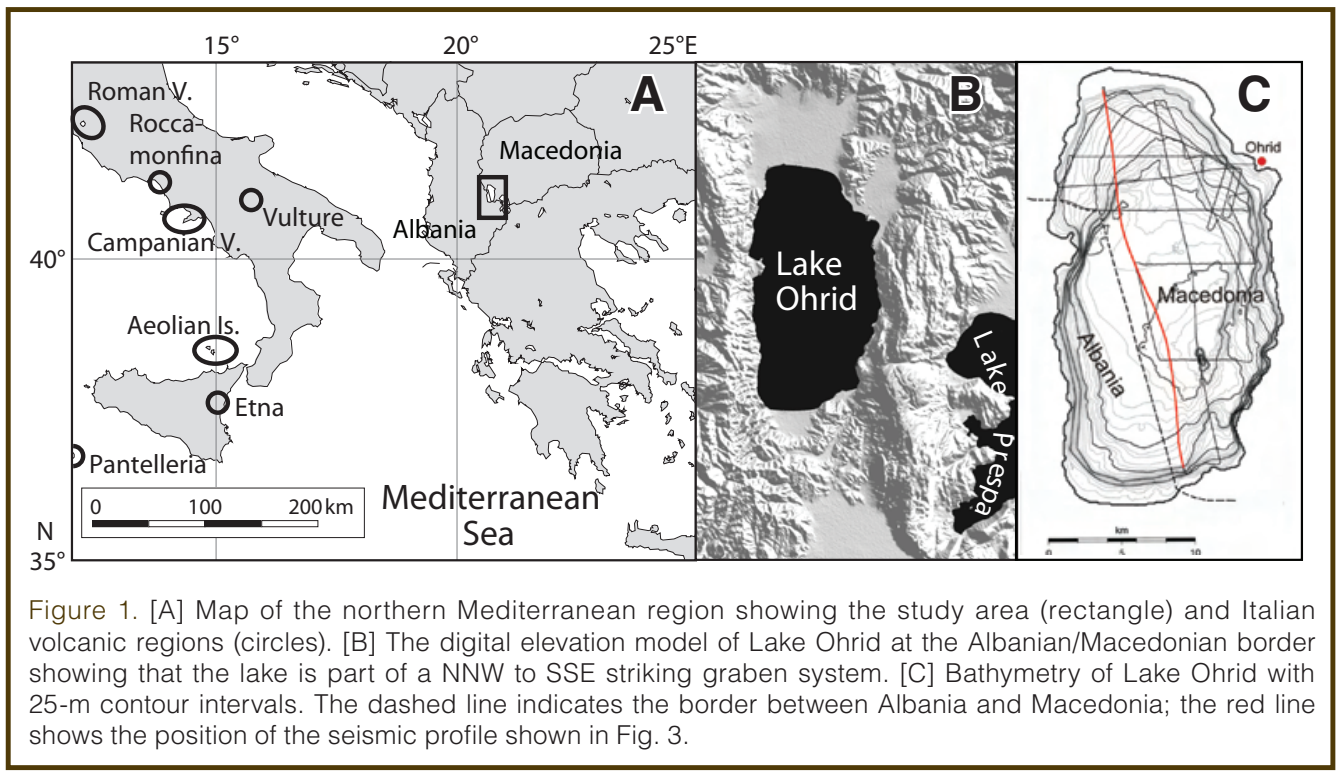




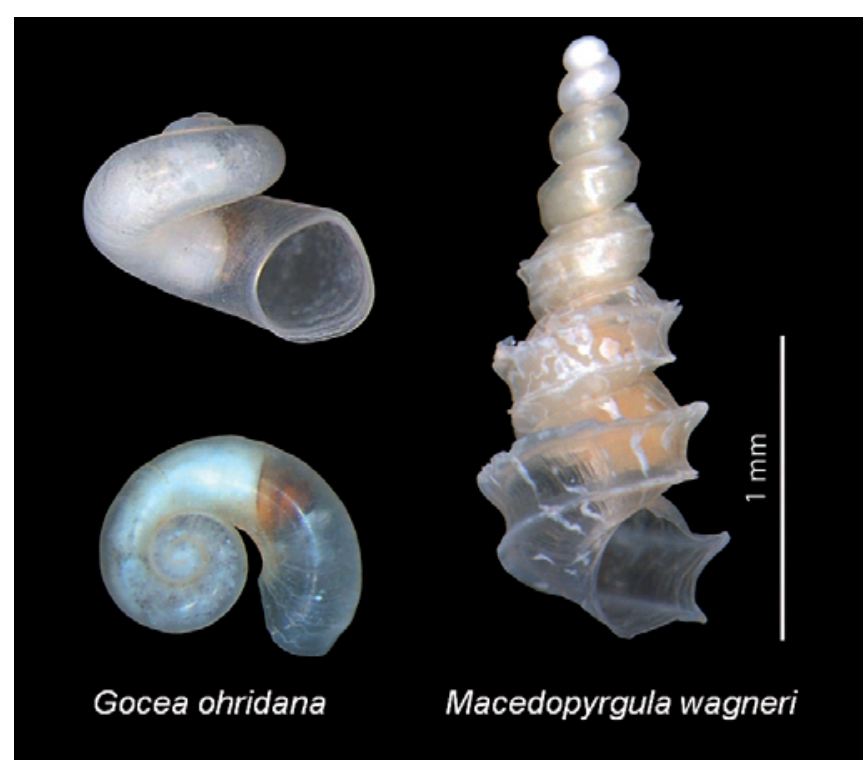

Figure 2. Photographs from two representatives of the more than 210 endemic species of Lake Ohrid.

- obtain more precise information about age and origin of the lake and, thus, meet key issues of International Continental Scientific Drilling Program (ICDP).

Under the auspices of the ICDP, on 13-17 October 2008 a workshop was held on the Scientific Collaboration On Past Speciation Conditions in Lake Ohrid (SCOPSCO) in the city of Ohrid, Republic of Macedonia. Its intent was to review the existing datasets and interpretations as well as discussions on objectives and intended achievements, required laboratory analyses and techniques, scientific collaboration and responsibilities, drill sites and operations, logistics, legal issues, and funding. Altogether, thirty-four scientists from eleven nations (Albania, France, Germany, Italy, Macedonia,
Netherlands, Poland, Sweden, Switzerland, U.K., and U.S.A.) participated in the workshop. The agenda included the presentation of posters and talks on the first day, the formation of breakout groups and a half-day excursion on the second day, and the presentation and discussion of the results and goals defined by the breakout groups, as well as a discussion of future steps towards deep drilling, on the third day.

Overall, nineteen talks provided a general introduction into the SCOPSCO project, the history of the region and the Hydrobiological Institute in Ohrid, and an overview on existing geological, recent biological, tectonic, and sedimentological datasets. In addition, five posters focusing on tectonic and biological aspects were presented. After the presentation of talks and posters on the first day, three breakout groups were formed in order to define the specific aims and drill sites of a future deep drilling campaign. The three breakout groups focused on the following topics: (1) speciation and endemism in Lake Ohrid, (2) seismic and neotectonic issues in Lake Ohrid and its vicinity, and (3) sedimentological and tephrostratigraphical questions to be addressed within the scope of the SCOPSCO project.

The breakout group on speciation and endemism in Lake Ohrid defined two to three drill sites close to recent subaquatic springs in the lake where a high degree of endemism can be observed. The seismic and neotectonic breakout group defined several drilling target sites on the basis of more than $500 \mathrm{~km}$ of seismic profiles across the lake (Figs. 1 and 3). Drilling less than about $200 \mathrm{~m}$ into the sediments at these sites will allow for a better understanding of the sediment input into the lake, the formation and chronology of foresets and slides (particularly in the southern part of the lake), and the fault development mainly along the western and eastern sides of the lake. One drill site was defined for sedimentological and tephrostratigraphical issues, including the reconstruction of the past environmental conditions at Lake Ohrid throughout its existence. This main drill site is located in the central, almost deepest part of the lake, where a sediment fill of about $700 \mathrm{~m}$ (Fig. 3) promises to contain the complete history of the lake back to its origin.

Possible overlaps, particularly between sites for studying neotectonic activities and those providing information to speciation and endemism around the 
springs, will reduce the number of total target sites to about five or six. For all sites, downhole logging and core logging issues were discussed and defined.

The excursion in the afternoon of the second day led to the Galicica Mountains, which separate lakes Ohrid and Prespa, and later to the southeastern part of Lake Ohrid to visit St. Naum springs, which form a major part of the water supply to the lake. The third day of the workshop focused on future steps towards an ICDP deep drilling campaign, with respect to logistic and legal issues, funding within the scope of national and international programs, and support by local ministries and institutes. Finally, the schedule for submission of a full proposal was established.

In summary, the SCOPSCO workshop provided a reliable platform to discuss the present state of knowledge and future steps towards a deep drilling campaign. A full proposal for an ICDP drilling campaign will be submitted in 2009 .

\section{Acknowledgements}

The SCOPSCO workshop was hosted by the Hydrobiological Institute in Ohrid, Republic of Macedonia, and funded by the International Continental Scientific Drilling Program (ICDP) and the Ministry of Environment and Physical Planning and the Ministry of Education and Science of the Republic of Macedonia.

\section{References}

Albrecht, C., and Wilke, T., 2008. Ancient Lake Ohrid: biodiversity and evolution. Hydrobiologia, 615:103-140, doi:10.1007/ s10750-008-9558-y.

Belmecheri, S., von Grafenstein, U., Bordon, A., Andersen, N., Lézine, A.M., Mazaud, A., and Grenier, C., 2007. Last Glacial-interglacial cycle palaeoclimatology and palaeoecology reconstruction in the southern Balkans: an ostracode stable isotope record from Lake Ohrid (Albania). Geophys. Res. Abstr., 9:09622.

Denèfle, M., Lézine, A.M., Fouache, E., and Dufaure, J.J., 2000. A 12,000 year pollen record from Lake Maliq, Albania. Quat. Res., 54:423-432, doi:10.1006/qres.2000.2179.

Geraga, M., Tsaila-Monopolis, S., Ioaim, C., Papatheodorou, G., and Ferentinos, G., 2005. Short-term climate changes in the southern Aegean Sea over the last 48,000 years. Palaeogeogr. Palaeoclimatol. Palaeoecol., 220:311-332, doi:10.1016/j. palaeo.2005.01.010.

Matzinger, A., Schmid, M., Veljanoska-Sarafiloska, E., Patceva, S., Guseka, D., Wagner, B., Sturm, M., Müller, B., and Wüest, A., 2007. Assessment of early eutrophication in ancient lakes - A case study of Lake Ohrid. Limnol. Oceanogr., 52:338-353.

Roelofs, A.K., and Kilham, P., 1983. The diatom stratigraphy and paleoecology of Lake Ohrid, Yugoslavia. Palaeogeogr. Palaeoclimatol. Palaeoecol., 42:225-245, doi:10.1016/ 0031-0182(83)90024-X.
Sadori, L., and Narcisi, B., 2001. The postglacial record of environmental history from Lago di Pergusa, Sicily. The Holocene, 11:655-670, doi:10.1191/09596830195681.

Schmiedl, G., Hemleben, C., Keller, J., and Segl, M., 1998. Impact of climatic changes on the benthic foraminiferal fauna in the Ionian Sea during the last 330,000 years. Paleoceanography, 13:447-458, doi:10.1029/98PA01864.

Tzedakis, P.C., Andrieu, V., de Beaulieu, J.-L., Crowhurst, S., Follieri, M., Hooghiemstra, H., Magri, D., Reille, M., Sadori, L., Shackleton, N.J., and Wijmstra, T.A., 1997. Comparison of terrestrial and marine records of changing climate of the last 500,000 years. Earth Planet. Sci. Lett., 150:171-176, doi:10.1016/S0012-821X(97)00078-2.

Wagner, B., Lotter, A.F., Nowaczyk, N., Reed, J.M., Schwalb, A., Sulpizio, R., Valsecchi, V., Wessels, M., and Zanchetta, G., 2008a. A 40,000-year record of environmental change from ancient Lake Ohrid (Albania and Macedonia).J. Paleolimnol., (in press), doi: 10.1007/s10933-008-9234-2.

Wagner, B., Reicherter, K., Daut, G., Wessels, M., Matzinger, A., Schwalb, A., Spirkovski, Z., and Sanxhaku, M., 2008b. The potential of Lake Ohrid for long-term palaeoenvironmental reconstructions. Palaeogeogr. Palaeoclimatol. Palaeoecol., 259:341-356, doi:10.1016/j.palaeo.2007.10.015.

Wijmstra, T.A., 1969. Palynology of the first $30 \mathrm{~m}$ of a $120 \mathrm{~m}$ deep section in northern Greece. Act. Bot. Neerl., 18:511-527.

\section{Authors}

Bernd Wagner, Institute of Geology and Mineralogy, University of Cologne, Zülpicher Str. 49a, D-50674 Köln, Germany, e-mail: wagnerb@uni-koeln.de.

Thomas Wilke, Animal Ecology and Systematics, Justus Liebig University Giessen, Heinrich-Buff-Ring 26-32, D-35392 Giessen, Germany.

Sebastian Krastel-Gudegast, Leibniz Institute of Marine Sciences (IFM-GEOMAR), Wischhofstr. 1-3, D-24148 Kiel, Germany.

Andon Grazhdani, Universiteti Politeknik, Fakulteti i Gjeologjise dhe Minierave, Tiranè, Albania.

Klaus Reicherter, Lehr- und Forschungsgebiet Neotektonik und Georisiken, RWTH Aachen University, Lochnerstr. 4-20, D-52056 Aachen, Germany.

Sasho Trajanovski, Hydrobiological Institute Ohrid, Naum Ohridski 50, 6000 Ohrid, Republic of Macedonia.

Giovanni Zanchetta, Dipartimento di Scienze della Terra, University of Pisa, Via S. Maria 56, I-56126 Pisa, Italy.

\section{Related Web Links}

http://www.geologie.uni-koeln.de/lake_ohrid.html http://ohrid.icdp-online.org

\section{Photo Credits}

Fig. 1: Wagner et al., 2008b

Fig. 2: photo by T. Wilke 